\title{
Laboratory and Field Studies Related to the Radionuclide Migration Project
}

\section{October 1, 1984-September 30, 1985}

\author{
Compiled and Edited by Joseph L. Thompson
}

\section{Contributols}
B. P. Bayhurst
S. Maestas
M. R. Cisneros
A. J. Mitchell
D. B. Curtis
T. W. Newton
J. Drake
A. E. Ogard
D. W. Efurd
M. A. Ott
J. D. Gallagher
P. D. Palmer
L. S. Hersman
R. S. Rundberg
D. E. Hobart
J.F. Sledgianowski
S. D. Knight
K.W. Thomas
G. W. Knobeloch
J. L. Thompson
F. O. Lawrence
B. J. Travis

\section{DISCLAIMER} \begin{abstract}
This report was prepared as an account of work sponsored by an agency of the United States
Government. Neither the United States Government nor any agency thereof, nor any of their
employes, makes any warranty, express or implied, or assumes any bility for the accuracy, completeness, or usefulness of assumes any legal liability or responsiprocess disclosed, or represents that its use fulness of any information, apparatus, product, or enee herein to any specific commercial use would not infringe privately owned rights. Refer. manufacturer, or otherwise does not necessail, process, or service by trade name, trademark mendation, or favoring by the United States constitute or imply its endorsement, recomand opinions of authors expressed States Government or any agency thereof. The views United States Government or any agency thereof necessarily state or reflect those of the
\end{abstract}




\section{CONTENTS}

ABSTRACT . . . . . . . . . . . . . . . . . . . . . . . . . . . . 1

I. INTRODUCTION . . . . . . . . . . . . . . . . . . . . . . . . . 2

II. CAMBRIC STUDIES . . . . . . . . . . . . . . . . . . . . . . . . 2

A. Sampling and Counting Methodologies . . . . . . . . . . . . . . 3

B. Tritium Migration . . . . . . . . . . . . . . . . . . . . . . . 5

C. Krypton Migration . . . . . . . . . . . . . . . . . . . . . . . 6

D. Anion Migration . . . . . . . . . . . . . . . . . . . . . . . . 10

E. Cation Migration . . . . . . . . . . . . . . . . . . . . . . . . 12

III. CHESHIRE STUDIES . . . . . . . . . . . . . . . . . . . . . . . 12

A. Radionuclides at 1200 and $820 \mathrm{~m}$. . . . . . . . . . . . . . . . . 14

B. Comparison with Cambric . . . . . . . . . . . . . . . . . . . . 18

C. Data Interpretation . . . . . . . . . . . . . . . . . . . . . . . 20

IV. STUDIES AT OTHER NTS SITES . . . . . . . . . . . . . . . . . . . 21

V. LABORATORY AND COMPUTATIONAL WORK . . . . . . . . . . 21

REFERENCES . . . . . . . . . . . . . . . . . . . . . . . . . . 23 


\section{LABORATORY AND FIELD STUDIES RELATED TO THE RADIONUCLIDE MIGRATION PROJECT}

October 1, 1984 -September 30, 1985

Compiled and Edited by Joseph L. Thompson

Contributors

$\begin{array}{ll}\text { B. P. Bayhurst } & \text { S. Maestas } \\ \text { M. R. Cisneros } & \text { A. J. Mitchell } \\ \text { D. B. Curtis } & \text { T. W. Newton } \\ \text { J. Drake } & \text { A. E. Ogard } \\ \text { D. W. Efurd } & \text { M. A. Ott } \\ \text { J. D. Gallagher } & \text { P. D. Palmer } \\ \text { L. S. Hersman } & \text { R. S. Rundberg } \\ \text { D. E. Hobart } & \text { J. F. Sledgianowski } \\ \text { S. D. Knigh. } & \text { K. W. Thomas } \\ \text { G. W. Knobeloch } & \text { J. L. Thompson } \\ \text { F. O. Lawrence } & \text { B. J. Travis }\end{array}$

ABSTRACT

In this report we review work performed in FY 1985 for the Radionuclide Migration program. Monitoring of water pumped from the satellite well at the Cambric site shows the continuing elution of tritium and krypton from the cavity but no appearance of fission-product cations. Water samples taken from two different depths in the re-entry hole at Cheshire have rather similar concentrations of radionuclides. This result, along with anomolously low tritium concentrations, makes the interpretation of data from Cheshire somewhat uncertain. We have made significant progress in laboratory studies of radionuclide sorption, actinide speciation, and colloid detection and migration. 


\section{INTRODLCTION}

The Radionuclide Migration (RNM) project is an interagency program initiated in 1973: its goal is to determine the extent to which radionuclides produced by underground nuclear tests move within or outside the boundaries of the Nevada Test Site (NTS). Participating organizations include Los Alamos National Laboratory. Lawrence Livermore Sational Laboratory the LS Geological Survey. the Desert Research Institute the Vevada ()perations Office of the L's Department of Energy. and various support organizations at the NTS. Los Alamos National Laboratorys contributions to the RNAl program are in radionuclide detection. geochenistry. and the study of redionuclide/rock interactions. Wo have two prineipal studv areas at the NTS. one at Frenchman Flat in Area 5 and the othere on Pahute Mesa in Irea 20. At the Cambric site in Area 5 . a large-scale tield study has been under way since 1974 and las provided a great deal of information concerning the movement of radioactive species through tuffaceous alluvium. The ('heshire site in Area 20 provides the rpportunity to study radionuclide movement in fractured rhyolite. Although the levels of radioactivity at both of these sites are relatively low and

are not hazardous from a health physic's perspective. a wide variety of radioactive species are present in sufficient concentrations so that we can study their behavior in a natural underground environment with a hydranlic gradient. Thus we can corroborate predictions based on laboratory studies and validate mathematical models that describe radionuclide migration. There are obvions areas of mutual interest between the RNM program and the Vevada Vuclear Waste Storage Investigations (NNWSI) project. and Los Alamos personnel contribute to both programs.

In this report we will review the work accomplished in the RNM program at the Cambric and Cheshire study sitis and at several other sampling sites on the NTS. We will also identify studies conducted at the Laboratory that have a direct bearing on RNM programmatic interests.

\section{II. ('AMBRIC STUDIES}

In May 1965. the nuclear test Cambric was conducted at Frenchman Flat on the NTS. The detonation point was $73 \mathrm{~m}$ below the water table (and $294 \mathrm{~m}$ below the ground 
surface) in tuffaceous alluvium; disruption of the site caused by the 0.75 -kt yield was relatively small. ()n re-entry of the Cambric ca ity 9 years after the test, we found that the tritium and fission products had remained in the cavity and chimney regions, and we were able to measure the distribution of radionuclides between the water and soil. To determine how the radioactive material would respond to water movement, we created an artificial hydratilic gradient by pumping water from a satellite well $91 \mathrm{~m}$ from the cavity. This well has been pumped continuously since 1975; there has been frequent sampling of the effluent water pumped from the RNM-2S satellite well and occasional sampling of the "avity water rin the re-entry R.NM-1 hole. Our work at the Cambric site has been described in a number of articles ${ }^{1-3}$ and annual reports. ${ }^{4-8}$ In this report we present data aceumulated during the past year and discuss how these data are related to information acquired in previous years.

\section{A. Sampling and Counting Methodologies}

The quantities of radionuclides present in the water at the RNM site are quite small in many instances: this has neessitated rather large sample volumes and long counting tines. In this section we will descrite the techniques we employ to collect and measure water samples from the RNM site and other similar locations at the NTS.

Water samples for tritium analyses are usually acquired by pumping tre water to the surface and collecting it in plastic bottles or jugs. Aliquots of 1 to $10 \mathrm{~m} \ell$ are taken for liquid scintillation counting: Insta-Gel (Packard Instrument Company) is used as the scintillation cocktail. Routine samples and background and tritium standards are counted repetitively for 50 -min periods. This technique allows us to measure activities down to background levels (about $5 \mathrm{dpm} / \mathrm{m} \ell$ ) with good precision, so our normal detection limits are approximately $2 \mathrm{pCi} / \mathrm{m} \ell$ or $5 \times 10^{7}$ atoms of tritium $/ \mathrm{m} \ell$ of sample. We can count samples with lower concentrations of tritium. but that requires longer counting periods to achieve good precision.

Water samples to be analyzed for ${ }^{85} \mathrm{Kr}$ are collected in evacuated $2-\ell$ stainless steel tubes that are filled from hose bibs for surface-level samples or lowered into the well for at-depth samples. The water is transferred from these "pressurized tubes" on a vacuum 
line and purged with a krypton carrier gas: the gas is then purified and collected in a connting contanes wht a thin titanimu window. A propane gas How proportional counter is loaded alternatcly with background samples. $85 \mathrm{Kr}$ standards. and the samples being andyzed. The krypon samples are repetitively counted for 100-min counting inservals over a periol of soreral woeks. and the clecay curve is checked against that expected for ${ }^{85} \mathrm{Kr}$. The detection levels for this combing regimen are similar to the background for the systom. Which is atount lis dem/mi of gas or ahout $3 \times 10^{5}$ atoms of ${ }^{85} \mathrm{Kr} / \mathrm{m} f$ of water. As

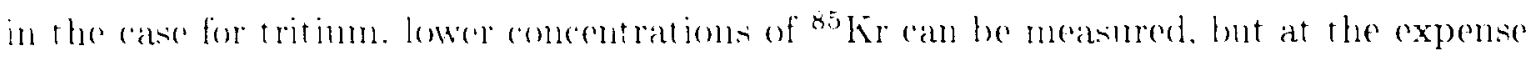
of longer rounting times.

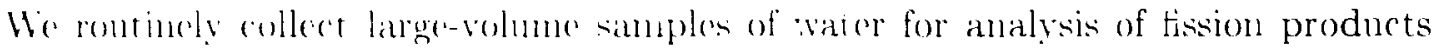
and for storige in arehival collections. These samples are pumped into 55-gal. plasticlined stres barrels that are used only once. Wa analyze for gamma-emitting radionuclides by concentr.:ing the water in a glass still to a volune of several liters. evaporating the roncentrate to dryness. and foming the rosidno into a cylindrical solid that is counted with a germanimm detertor and associated multichannol andyzer. A computer program translates pammataly intemsities into atoms of a particulat radionnclide and corrects to

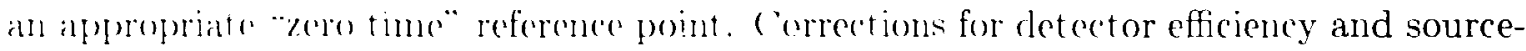
detertor gometry are evahuated by a combing standard: the standard is made by doping a barrel of clean water (from Well 5B at the XTS) with a suite of NBS-certified gamma'mitting radionuclides and evaporating it to dryness. Background corrections are made from ewaporated 55-gal. samples of Woll $5 \mathrm{~B}$ water that are free of detectable levels of fission products. The gemmanimn detector is shiolded to minimize gamma radiation from the cminomment as woll as seattered radiation from the souree: comnting times usually inchude a $100(1-$ and $4000-1 m i n$ comnt to optimize the actuvity levels present in samples from ('anbric. l sing this collection and comnting system. we can detect ${ }^{137}$ Cs at concentration l.vels of about $1 \times 10^{3}$ atoms/ml of sample.

Wo moasure ${ }^{90} \mathrm{Sr}$ in $2-\ell$ water samples by concentrating the sample and then precipitating strontium as the nitrate. After a series of chromate precipitations to remove any harimm contamination. the strontium is converted to the carbonate and then counted. The ingrowth of the ${ }^{90} \mathrm{Yt}$ daughter is monitored. which both increases the sensitivity of 
the method and allows a check for any spurious beta activity in the final precipitate. The sensitivity of this method is approximately $5 \times 10^{5}$ acoms of ${ }^{90} \mathrm{Sr} / \mathrm{m} \ell$.

Our radiochemical procedure for ${ }^{137} \mathrm{Cs}$ involves purifying the sample and counting the cesium perchlorate precipitate. After the $2-\ell$ sample is concentrated, the cesium is precipitated as the perchlorate and then dissolved and precipitated as a silicotungstate. W'e do several additional perchlorate precipitations interspersed with ferric hydroxide scavanger procedures to ensure the final purity of the product. The cesium, appropriate reagent blanks. and standard sources are gamma counted. The sensitivity of our radiochemical method for ${ }^{137} \mathrm{Cs}$ is about $1 \times 10^{6}$ atoms $/ \mathrm{m} \ell$.

Plutonium in our samples is analyzed after they are radiochemically purified by alpha counting using a Frisch grid detector. The purification process involves oxidation with perchloric axid. extraction with HDEHP (di-2-ethylhexyl phosphoric acid), precipitation with lanthanum fluoride, sorption on an anion exchange resin, and drying of the final eluate on a platinum plate. The chemical yield through the purification steps is determined by adding a ${ }^{236} \mathrm{Pu}$ tracer to the initial $4-\ell$ water sample. The method is so sensitive that about $1 \times 10^{6}$ atoms of ${ }^{239} \mathrm{Pu}$ can be detected in $1 \mathrm{~m} \ell$ of sample.

In addition to the routine procedures just described, we also employ such analytical techniques as tandem-accelerator mass s'sectrometry, neutron activation analysis, and isotope dilution mass spectrometry to mrasure radionuclides like ${ }^{36} \mathrm{Cl},{ }^{129} \mathrm{I}$, and ${ }^{99} \mathrm{Tc}$ that may be present at very low concentrations in our samples. We discuss the use of these techniques in previous reports ${ }^{5,6}$ and in Sec. II.D. of this report.

\section{B. Tritium Migration (J. L. Thompson and S. Maestas)}

During the past year the pump in the RNM-2S satellite well continued to operaite at about $600 \mathrm{gal} / \mathrm{min}$, and the tritium content of the pumped water continued to decline. The tritium concentration data for this year are tabulated in Table I, and complete elution curves are shown in Figs. 1 and 2. Through the end of September 1985, we had pumped about $3.9 \times 10^{4} \mathrm{Ci}$ of tritium from RNM-2S, which is $65 \%$ of the original inventory. As the shape of the elution tail becomes better defined, we will be able to compare our model predir ${ }^{\perp}$ ions ${ }^{6,8}$ with reality. 


\section{TABLE I}

\section{TRITIUM ANALYSES OF RNM-2S WATER SAMPLES}

\begin{tabular}{|c|c|c|c|}
\hline $\begin{array}{l}\text { Identification } \\
\text { Number }\end{array}$ & Date & $\begin{array}{c}\text { Volume Pumped } \\
\left(10^{6} \text { gals. }\right)\end{array}$ & $\begin{array}{c}\text { Tritium }^{a} \\
\left(10^{3} \mathrm{pCi} / \mathrm{m} \ell\right) \\
\end{array}$ \\
\hline G 1437 & $10 / 18 / 84$ & 2500.7 & 1.38 \\
\hline G $1 \dot{4} 38$ & $11 / 16 / 84$ & 2525.5 & 1.36 \\
\hline G 1439 & $12 / 21 / 84$ & 2554.5 & 1.34 \\
\hline (: 1440 & $01 / 25 / 85$ & 2583.3 & 1.28 \\
\hline G 1441 & $02 / 21 / 85$ & 2605.5 & 1.28 \\
\hline G 1442 & $03 / 18 / 85$ & 2626.0 & 1.25 \\
\hline () 1443 & $04 / 19 / 85$ & 2652.3 & 1.21 \\
\hline G 1444 & $05 / 21 / 85$ & 2680.1 & 1.19 \\
\hline G 1445 & $06 / 03 / 85$ & 2691.4 & 1.19 \\
\hline G 1446 & $07 / 01 / 85$ & 2715.4 & 1.16 \\
\hline G 1447 & $08 / 16 / 85$ & 2754.8 & 1.10 \\
\hline G 1448 & $09 / 04 / 85$ & 2771.1 & 1.12 \\
\hline
\end{tabular}

${ }^{a}$ Standard deviation of counting data $<1 \%$.

C. Krypton Migration (J. L. Thompson, S. Maestas, and F. O. Lawrence)

In Table II we present the data from our inonthly analyses of ${ }^{85} \mathrm{Kr}$ from water collected in the gas-tight pressurized tubes. The complete elution curve of krypton from RNM-2S is shown in Fig. 3. It is apparent that the maximum in this curve occurred at a volume of 6 to $7 \times 10^{6} \mathrm{~m}^{3}$, whirh is significantly delayed relative to the maximum in the tritium eintion curve. This suggests that the krypton is held up slightly during its passage through the alluvium, although in general it moves with the tritium. The atom ratic of krypton to tritiun, shown in Fig. 4. continues to increase slightly but is still below the calculated source term ratio of $1.22 \times 10^{-4}$.

Our annual pumping from the Cambric cavity at RNM-1 yields samples that reflect the continued loss of tritium and krypton from this region. The tritium concentrations at RNM-1 are given in Table III, and in Table IV both tritium and krypton concentrations are shown with previously measured values. It appears that the tritium is now being removed from the cavity region more rapidly than is the krypton, perhaps because krypton 


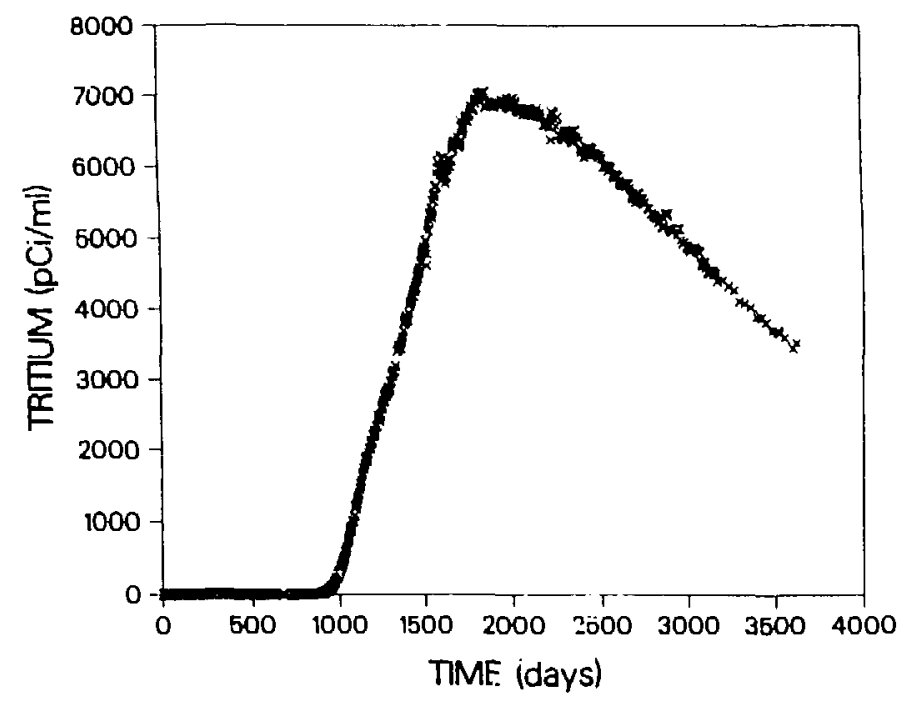

Fig. 1. Tritium concentration in water pumped from RNM-2S $v s$ time. Values are corrected to Cambric zero time.

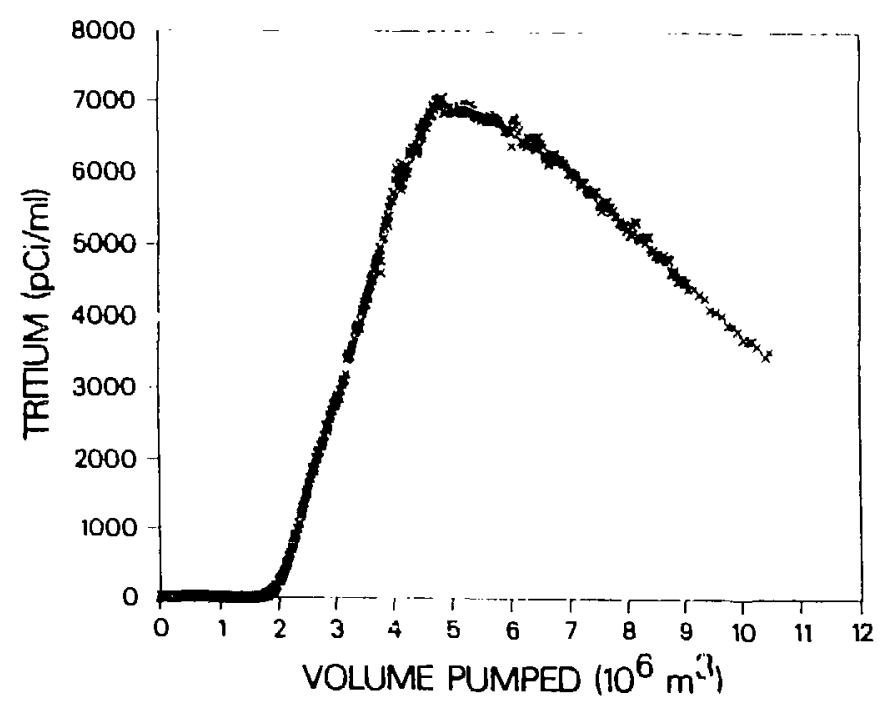

$\mathrm{F}: \approx$. 2. Tritium concentration in water pumped from RNM-2S vs volume pumped. Values are corrected to Cambric zero time. 
TABLE II

TRITIUM AND ${ }^{85} \mathrm{KI}$ ANALYSES ()F PRESTIRIZLI)

WATER SAMILES FROM RNM-2S'

\begin{tabular}{|c|c|c|c|c|c|c|c|c|}
\hline \multirow{3}{*}{$\begin{array}{c}\text { Identification } \\
\text { Number }\end{array}$} & \multirow{3}{*}{$\begin{array}{c}\text { Date } \\
\text { Collected } \\
\end{array}$} & \multirow{3}{*}{$\begin{array}{l}\text { Volume } \\
\text { Pumped } \\
\left(10^{6}: 11^{3}\right)\end{array}$} & \multirow{2}{*}{\multicolumn{2}{|c|}{ Tritimu ('oncontration }} & \multirow{2}{*}{\multicolumn{2}{|c|}{${ }^{85} \mathrm{Kr}$ comcentration }} & \multicolumn{2}{|c|}{${ }^{85} \mathrm{Kr} / \mathrm{Tritinm}$} \\
\hline & & & & & & & Atom Ration & \\
\hline & & & $\underline{(11(: i / 111 \ell)}$ & $\left(10^{10}:\right.$ illonis/n11 $)$ & $(\mathrm{d} p \mathrm{mu} / \mathrm{ml} \mathrm{f})$ & $\left(10^{6}\right.$ atconss $\left./ 1118\right)$ & $\times 10^{5}$ & Riltiob \\
\hline $434-1-84-(016$ & $10 / 04 / 84$ & 9.423 & 4.07 & $x .47$ & 0.749 & 6.12 & 7.22 & 0.59 \\
\hline $434-1-84-018$ & $11 / 02 / 81$ & 9.515 & $4 .() 2$ & 8.37 & 0.678 & 5.54 & 6.62 & 0.54 \\
\hline $434-1-84-() 20$ & $12 / 06 / 84$ & 9.625 & 3.91 & 8.14 & 0.535 & 4.37 & 5.37 & 0.44 \\
\hline $434-1-85-004$ & $02 / 15 / 85$ & 9.847 & 3.86 & $8.1) 3$ & 0.643 & 5.25 & 6.54 & 0.54 \\
\hline $434-1-85-005$ & $03 / 01 / 85$ & 9.890 & 3.84 & 7.99 & 0.649 & 5.29 & 6.62 & 0.54 \\
\hline $434-1-85-010$ & $05 / 21 / 85$ & 10.146 & 3.66 & 7.61 & 0.606 & 4.94 & 6.49 & 0.53 \\
\hline $434-1-85-011$ & $06 / 03 / 85$ & 10.188 & 3.70 & 7.70 & 0.596 & 4.87 & 6.32 & $(0.52$ \\
\hline $434-1-85-013$ & $07 / 01 / 85$ & 10.279 & 3.60 & 7.49 & 0.563 & 4.62 & 6.17 & 0.51 \\
\hline $434-1-85-014$ & $07 / 01 / 85$ & 10.279 & 3.63 & 7.55 & 0.632 & 5.17 & 6.85 & 0.56 \\
\hline
\end{tabular}

${ }^{a}$ All activity levels corrected to Cambric zero timo (May 14. 1965).

${ }^{b}$ Measured ${ }^{85} \mathrm{Kr} /$ tritium atom ratio divided by ${ }^{85} \mathrm{Kr} /$ tritium atom ratio calculated for (ambric zero tine ( $1.22 \mathrm{x} 10^{-4}$ ). 


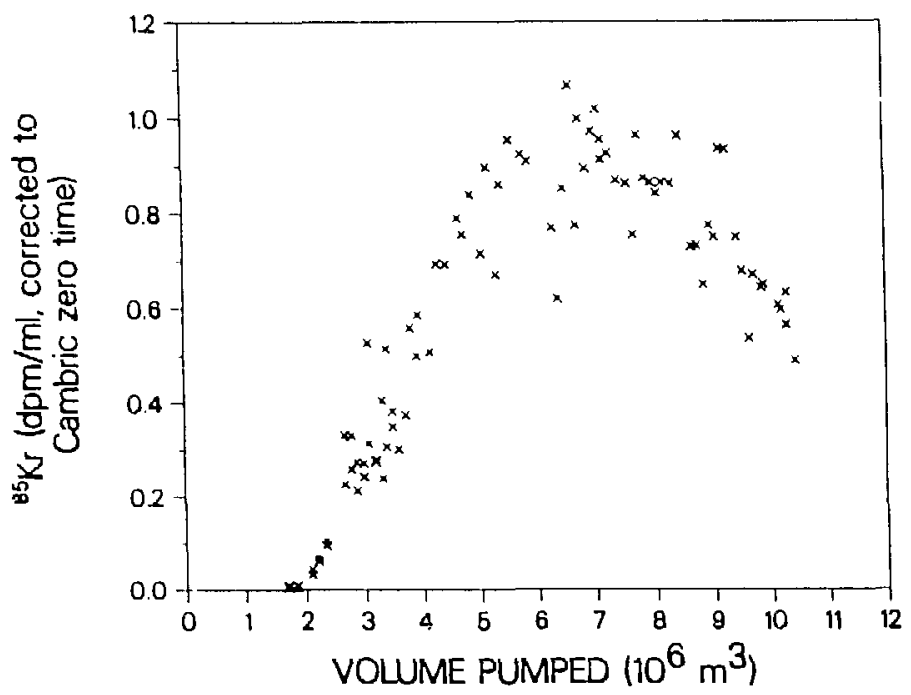

Fig. 3. The ${ }^{85} \mathrm{Kr}$ concentration in water pumped from RNM-2S. Values are corrected to Cambric zero time.

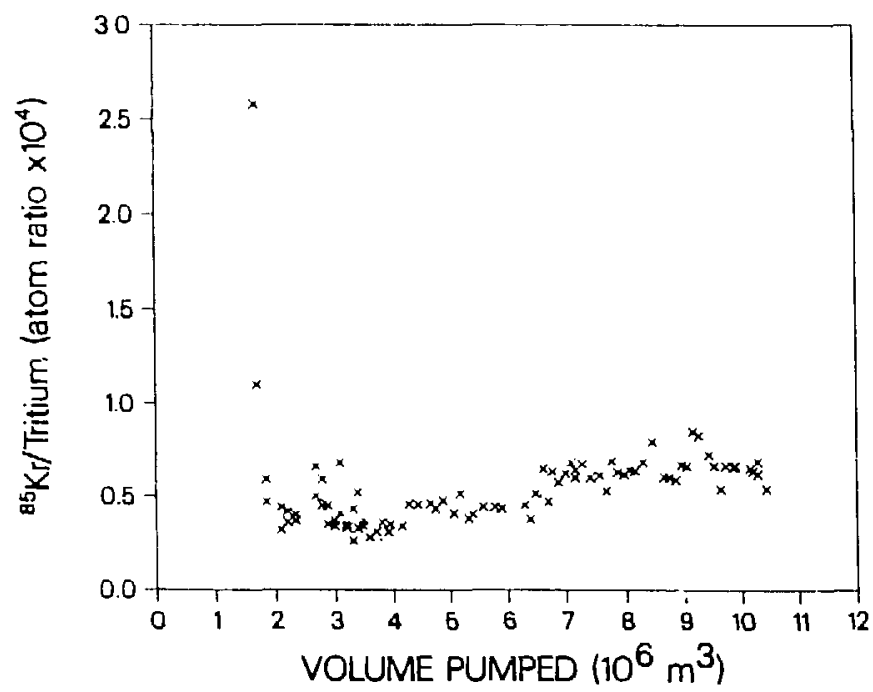

Fig. 4. Atom ratio of ${ }^{85} \mathrm{Kr}$ to tritium in water pumped from RNM-2S. Values are corrected to Cambric zero time. 
TABLE III

TRITIUM CONCENTRATION IN RNM-1 WATER (1985)

Tritium Concentration

\begin{tabular}{|c|c|c|c|}
\hline \multirow[b]{2}{*}{$\begin{array}{l}\text { Identification } \\
\text { Number }\end{array}$} & \multirow{2}{*}{$\begin{array}{c}\text { Volume } \\
\text { Pumped } \\
\left(\mathrm{m}^{3}\right) \\
\end{array}$} & \multicolumn{2}{|c|}{$(\mathrm{pCi} / \mathrm{m} \ell)$} \\
\hline & & $\begin{array}{l}\text { On Collertion } \\
\text { Date } 4 / 10 / 85\end{array}$ & $\begin{array}{l}\text { Corrected to } \\
\text { Cambric } t_{0} 5 / 14 / 65\end{array}$ \\
\hline R-1 & 2.3 & 3.5 & 11 \\
\hline $\mathrm{R}-2$ & 13.6 & 3.6 & 11 \\
\hline R-3 & 25.7 & 3.4 & 10 \\
\hline$R-4$ & 39.4 & 3.5 & 11 \\
\hline $\mathrm{R}-5$ & 51.5 & 3.6 & 11 \\
\hline$R-6$ & 60.7 & 3.7 & 11 \\
\hline $\mathrm{R}-7$ & 68.9 & 4.2 & $1: 3$ \\
\hline $434-3-85-001^{a}$ & 71.2 & 4.1 & $\underline{13}$ \\
\hline & & & Average 11 \\
\hline
\end{tabular}

${ }^{a}$ Collected in gas-tight pressurized tubes.

that initially sorbed on (or into) the alluvium now is being leached out. Note that the krypton/tritium atom ratio in the cavity region has remained well above the calculated source-term ratio.

D. Anion Migration (J. L. Thompson, J. F. Sledgianowski, and D. B. Curtis)

The nuclear test at Cambric produced relatively small quantities of ${ }^{36} \mathrm{Cl}$ and ${ }^{129} \mathrm{I}$, and a portion of these radionuclides were dissolved in the groundwater at RNM-1. For example, we calculate ${ }^{8}$ that about $40 \%$ of the product ${ }^{129}$ I was contained in the groundwater when we re-entered RNM-1 in 1974. Anions move through the alluvial soil at the Cambric site with minimal sorption, and both ${ }^{36} \mathrm{Cl}$ and ${ }^{129} \mathrm{I}$ have been detected in the water pumped from RNM-2S (Refs. 6 and 7).

Because of the very long periods required to obtain analyses of our ${ }^{36} \mathrm{Cl}$ samples by tandem-accelerator mass spectrometry, we are trying to develop alternative means of analysis. Liquid scintillation counting of ${ }^{36} \mathrm{Cl}$ is feasible if the samples can be sufficiently 
TABLE iV

TRITILM AND ${ }^{85} \mathrm{Kr}$ CON(ENTRATIONS IN RNM-1 WATER

\begin{tabular}{|c|c|c|c|c|c|c|}
\hline \multirow[b]{2}{*}{ Zune } & \multirow[b]{2}{*}{ Dito } & \multirow{2}{*}{$\begin{array}{l}\text { Volume } \\
\text { P'umped }^{a} \\
\left(10^{6} \mathrm{~m}^{3}\right)\end{array}$} & \multicolumn{2}{|c|}{ Concentration $^{b}$} & \multicolumn{2}{|c|}{${ }^{85} \mathrm{Kr} /$ Tritium } \\
\hline & & & $\begin{array}{c}\text { Tritium } \\
\left(10^{9} \text { atoms } / \mathrm{m} \ell\right)\end{array}$ & $\begin{array}{c}{ }^{85} \mathrm{Kr} \\
\left(10^{6} \text { atorms } / \mathrm{m} \ell\right)\end{array}$ & $\begin{array}{c}\text { Atom Ratio } \\
\times 10^{4} \\
\end{array}$ & Ratió \\
\hline Origirial-Zone IV & $(68 / 08 / 75$ & 0. & 3100 & 570. & 1.5 & 1.5 \\
\hline () riginal-Zone $\mathrm{V}$ & $(18 / 14 / 75$ & 0. & 790 & 110 & 1.4 & 1.2 \\
\hline Zone $I V+V$ & $10 / 04 / 77$ & 1.17 & 66. & 610. & 92 & 75 \\
\hline Zone IV + V & $11 / 30 / 77$ & 1.34 & 41. & 49. & 12 & 10 \\
\hline Zonic Ii + 1 & $09 / 04 / 79$ & 3.50 & 5.4 & 4.6 & 8.5 & 7 \\
\hline Zune $I V+V$ & $10 /(05 / 81$ & 5.89 & 3.0 & 1.5 & 5.0 & 4 \\
\hline Zone $I V+V$ & $(04 / 01 / 82$ & 6.48 & 1.6 & 0.55 & 3.3 & 3 \\
\hline Zune il +1 & $01 / 06 / 83$ & 7.67 & 0.70 & 0.24 & 3.4 & 3 \\
\hline Zone il $+V$ & $(04 / 24 / 84$ & 8.91 & 0.46 & 0.19 & 4.1 & 3 \\
\hline Zone $I V+V$ & $04 / 10 / 85$ & 10.0 & 0.27 & 0.21 & 7.8 & 6 \\
\hline
\end{tabular}

"Total volume of water removed from RNM-2S by indicated date.

${ }^{b}$ Values corrected to ( ambric aero time.

c.Mcasured ${ }^{85} \mathrm{Kr} / \mathrm{tritimu}$ divided by ${ }^{85} \mathrm{Kr}$ /t ritiuni calculated for Cambric $\left(1.22 \times 10^{-4}\right)$.

concentrated and if interfering radionuclides are removed. We have developed a method of sample treatment involving precipitation of the chlorine with silver nitrate, filtration, and dissolution of the precipitate with sodium cyanide. Water samples of 10 to $20 \ell$ from RNM-2S yield counting samples with activities several times background levels. The method is sufficiently promising that we will continue development using NBS standard ${ }^{36} \mathrm{Cl}$.

We did no other analyses for anions during the past year but accomplished some preparative work that may eventually help us detect ${ }^{99} \mathrm{Tc}$ in $\mathrm{RNM}$ waters. We recently purified a ${ }^{97} \mathrm{Tc}$ source and calibrated it against $2 \mathrm{n} \mathrm{NBS}{ }^{99} \mathrm{Tc}$ standard. The ${ }^{97} \mathrm{Tc}$ was prepared by irradiating a ${ }^{96} \mathrm{Ru}$ target with neutrons to produce ${ }^{97} \mathrm{Ru}$, dissolving the target, extracting th: daughter ${ }^{97} \mathrm{Tc}$, and finally purifying it by using anion exchange resins. 
This ${ }^{97} \mathrm{Tc}$ can now be used in isotope dilution mass spectrometric analyses of ${ }^{99} \mathrm{Tc}$ in environmental samples.

E. Cation Migration (J. L. Thompson, S. Maestas, G. W. Knobeloch, J. Drake, D. W. Efurd, and J. D. Gallagher)

One of the original goals of the Cambric experimeıt was to determine rates with which various radioactive species would move from the cavity at RNM-1 to the well at RNM-2S under the impetus of a hydraulic gradient. As noted above, we have traced the movement of neutral species (tritiated warer, krypton) and anions (chlorine, iodine) during the 10 years we have pumped water from RNM-2S. To date, however, we have not detected in the RNM-2S any effluent species known to be cationic. We annually monitor the concentrations of the relatively long-lived fission products ${ }^{90} \mathrm{Sr}$ and ${ }^{137} \mathrm{Ce}$ at RNM-1, and although the concentrations have decreased with time, these radionuclides have not appeared at the satellite well. From the cumulative data in Table V it can be seen that the concentrations of ${ }^{90} \mathrm{Sr}$ and ${ }^{137} \mathrm{Ce}$ have not decreased in the cavity region as rapidly as has tritium. This probably indicates that some of the ions that were initially incorporated in the rock are now leaching out, giving relatively higher concentrations of these species. At some point in the future, a steady state may be achieved in which the leach rate and removal rate will be equal.

It is encouraging to note that the field test at RNM-1 confirms our pledictious, which were based on labora'sory studies: species with high sorption ratios are not readily transported through tuff by water. If ${ }^{90} \mathrm{Sr}$ or ${ }^{137} \mathrm{Ce}$ does appear at RNM-2S, it will be quite importar: to determine whether the radionuclide is in solution or has been transported in some other form (for example, as a colloid).

\section{CHESHIRE STUDIES}

The Cheshire test was conducted on Pahuce Mesa at the NTS in February 1976. The cavity region was re-er. ${ }^{2}$ ered in 1976, but only a small amount of water was pumped out before 1983. The cavity location is well below the water table and in a region where there are natural hydraulic gradients, so there is the potential for movement of radionuclides 
TABLE V

TRITIUM, ${ }^{90} \mathrm{Sr}$, AND ${ }^{137}$ (s (OONC'ENTRATIONS IN RNM-1 WATER

\begin{tabular}{|c|c|c|c|c|c|c|c|}
\hline \multirow[b]{3}{*}{ Zone } & \multirow[b]{3}{*}{ Date } & \multirow{3}{*}{$\begin{array}{c}\text { Volume } \\
\text { Pumped }^{a} \\
\left(10^{6} \mathrm{~m}^{3}\right) \\
\end{array}$} & \multicolumn{3}{|c|}{ Concentrations $^{b}$} & \multirow{2}{*}{\multicolumn{2}{|c|}{$\begin{array}{c}\text { Atom Ratio } \\
\times 10^{4} \\
\end{array}$}} \\
\hline & & & Tritium & ${ }^{90} \mathrm{Sr}$ & $137(9$ & & \\
\hline & & & $\left(10^{9}\right.$ atoms $\left./ \mathrm{m} \ell\right)$ & $\left(10^{6}\right.$ atoms $\left./ \mathrm{ml} \ell\right)$ & $\left(10^{6}\right.$ atoms/nl $\left./\right)$ & ${ }^{90} \mathrm{Sr} / \mathrm{T}$ & $137(\mathrm{~s} / \mathrm{T}$ \\
\hline Original-Zone IV & $08 / 08 / 75$ & 0. & 3100. & 130. & 23 & 0.4 & 0.07 \\
\hline Original-Zone V & $08 / 14 / 75$ & 0. & 790. & 5.5 & 4.6 & 0.07 & 0.06 \\
\hline Zone IV + V & $10 / 04 / 77$ & 1.17 & 66. & 22 & 5.5 & 3. & 0.8 \\
\hline Zone IV + V & $11 / 30 / 77$ & 1.34 & 41. & 13 & 11. & 3. & 3 \\
\hline Zone IV + V & $09 / 04 / 79$ & 3.50 & 5.4 & 4.4 & 2.3 & 8. & 4. \\
\hline Zone IV + V & $10 / 05 / 81$ & 5.89 & 3.0 & 1.5 & $1.3(1.6)^{c}$ & 5. & $4(5)^{c}$ \\
\hline Zone IV + V & $04 / 01 / 82$ & 6.48 & 1.6 & 1.3 & $1.5(1.5)^{c}$ & 8. & $9(8)^{c}$ \\
\hline Zone IV + V & $04 / 06 / 83$ & 7.67 & 0.70 & & $1.3(1.1)^{c}$ & & $19(16)^{c}$ \\
\hline Zone IV + V & $04 / 24 / 84$ & 8.91 & 0.46 & 0.81 & 1.0 & 17. & 23 \\
\hline Zone IV + V & $04 / 10 / 85$ & 10.0 & 0.27 & 0.55 & 1.0 & 20 & 37. \\
\hline
\end{tabular}

${ }^{a}$ Total volume of water removed from RNM-2S by indicated date.

${ }^{b}$ Values corrected to Cambric zero time.

${ }^{c}$ Values in parentheses are based on gamma-spretral analyses of 55-gal. (evaporated) samples. 
away from the explosion zcac. The rock in this region is brecciated rhyolitic lava. We began studing the Cheshire site because it offered the opportunity to observe radionuclide migration under natural conditions and because the rock type was different from that being studied at the Cambric site. We extensively sample 1 the wate: pumped from Cheshire in September 1983 and again in August and October 1984. Routine monitoring of tritium took place between these major sampling efforts. 'The water pumped from Cheshire in 198.3 and 1984 is supposed to have flowed into the re-entry hole through perforations in the casing at a depth of about $1200 \mathrm{~m}$, close to the level of the cavity. Hydrologic studies in the region suggest that the llatural direction of water movement is from the cavity to relatively permeable zones above. then laterally to the wuth and west. We wished to intercept water along this flow path, so in May 1985 the bottom of the hole was packed off; new perforations were made at a depth of approximately $820 \mathrm{~m}$ and punping was resumed. In June 1985 we collected a number of samples of the pumped water for comparisen with previous samples. In this report we present the results of three types of water analyses: (1) grab samples analyzed only for tritium, (2) pressurized samples analyzed for tritium and ${ }^{85} \mathrm{Kr}$. and (3) large-volume samples analyzed for gamma-ray-emitting radionuclides and ${ }^{90} \mathrm{Sr}$. The methodology employed in obtaining the sample and making the measurements was similar to thai described in Sec. II.A. Results of our analytical work before October 1984 and more details concerning the earlier h:story of Cheshire are given iı Ref. 8.

\section{A. Radionuclides at 1200 and $820 \mathrm{~m}$ (J. L. Thompson, S. Maestas, M. R. Cisneros,}

F. O. Lawrence, G. W. Knobeloch, D. W. Efurd, J. Drake, and J. D. Gallagher)

Analytical data from Cheshire are presented in Tables VI-VIII. Although Table VI contains tritium concentration values obtained in FY 1985 only, Table VII includes ${ }^{85} \mathrm{Kr}$ and tritium measurements made in previous years as well. During the past year we rebuilt and recalibrated the counter system used for gamma-ray analysis of evaporated largevolume samples, so we recounted earlier samples as well as new ones. We have included in Table VIII all the measurements made with the rebuilt counting system. We also listed measurements of tritium, ${ }^{85} \mathrm{Kr},{ }^{90} \mathrm{Sr},{ }^{137} \mathrm{Ce}$, and ${ }^{239} \mathrm{Pu}$ obtained by other techniques. 


\begin{tabular}{|c|c|c|c|}
\hline $\begin{array}{l}\text { Identification } \\
\text { Number } \\
\end{array}$ & Date & $\begin{array}{l}\text { Volume Pumped } \\
\left(10^{6} \text { gals. }\right)\end{array}$ & $\begin{array}{c}\text { Tritium } \\
10^{2}(\mathrm{n} \mathrm{Ci} / \mathrm{m} \ell)^{a} \\
\end{array}$ \\
\hline $852-1-84-001$ & $08 / 01 / 84$ & 0.17 & 5.40 \\
\hline$(-11$ & $10 / 03 / 84$ & 2.3 & 5.17 \\
\hline$C-12$ & $10 / 16 / 84$ & 2.8 & 5.16 \\
\hline$(c-13$ & $10 / 18 / 84$ & 2.8 & 5.16 \\
\hline $852-1-84-0013$ & $10 / 23 / 84$ & 3.0 & 5.20 \\
\hline $852-1-84-005$ & $10 / 23 / 84$ & 3.0 & 5.17 \\
\hline$C-14$ & $10 / 25 / 84$ & 3.1 & 5.14 \\
\hline$(-15$ & $04 / 24 / 85$ & 3.1 & 5.01 \\
\hline$(c-16$ & $04 / 26 / 85$ & 3.2 & 4.97 \\
\hline $852-1-85-001$ & $05 / 09 / 85$ & 3.4 & 4.95 \\
\hline $852-1-85-002$ & $05 / 09 / 85$ & 3.4 & 5.00 \\
\hline $852-1-85-003$ & $05 / 14 / 85$ & 3.5 & 4.58 \\
\hline $852-1-85-004$ & $05 / 14 / 85$ & 3.5 & 4.71 \\
\hline $\mathrm{C}-17$ & $05 / 29 / 85$ & 3.7 & 4.94 \\
\hline C. -18 & $06 / 05 / 85$ & 4.1 & 4.21 \\
\hline$C-19$ & $06 / 11 / 85$ & 4.4 & 4.32 \\
\hline $852-1-85-005$ & $06 / 18 / 85$ & 4.8 & 4.11 \\
\hline C -20 & $06 / 27 / 85$ & 5.2 & 3.30 \\
\hline C -21 & $07 / 05 / 85$ & 5.6 & 4.20 \\
\hline $\mathrm{C}-22$ & $07 / 12 / 85$ & 6.0 & 4.21 \\
\hline C- 23 & $07 / 17 / 85$ & 6.3 & 3.98 \\
\hline C-24 & $09 / 11 / 85$ & 6.4 & 3.17 \\
\hline
\end{tabular}

${ }^{a}$ Standard deviation of counting data $<1 \%$. Values are corrected $\iota t_{o}=02 / 14 / 76$.

The tritium concentration in water pumped from Cheshire has diminished as water is removed from the hole. Data from Table VI are plrtted in Fig. 5, and the approximately linear relationship ketween tritium concentration and volume pumped is apparent. It is particularly interesting that there is no change in the slope of the curve at the point (about $3.6 \times 10^{6}$ gals. pumped) when we began using the new perforations. This would seem to indicate that water drawn from the area adjacent to the cavity and water drawn from several hundred meters above the cavity contain the same amount of tritium-a very 
TABLE VII

TRITIUM AND ${ }^{85} \mathrm{Kr}$ ANALYSES OF PRESSURIZED

WATER SAMPLES FROM CHESHIRE

\begin{tabular}{|c|c|c|c|c|c|c|}
\hline \multirow[b]{2}{*}{ Zone } & \multirow[b]{2}{*}{ Date } & \multirow{2}{*}{$\begin{array}{c}\text { Volume } \\
\text { Pumped } \\
\left(10^{6} \text { gals. }\right)\end{array}$} & \multicolumn{2}{|c|}{ Concentration } & \multicolumn{2}{|c|}{${ }^{85} \mathrm{Kr} /$ Tritium } \\
\hline & & & $\begin{array}{c}{ }^{85} \mathrm{Kr} \\
\left(10^{9} \text { atoms } /\llcorner\cap \ell)\right.\end{array}$ & $\begin{array}{c}\text { Tritium } \\
\left(10^{12} \text { atoms/n } \ell\right)\end{array}$ & $\begin{array}{l}\text { Atom Ratio } \\
\times 10^{4} \\
\end{array}$ & Ratio $^{a}$ \\
\hline 852-1-83-008 & $09 / 09 / 83$ & 0.06 & 5.5 & 12.0 & 4.6 & 0.78 \\
\hline $852-1-83-009$ & $09 / 09 / 83$ & 0.06 & 5.9 & 11.6 & 5.1 & 0.86 \\
\hline $852-1-84-001$ & $08 / 01 / 84$ & 0.17 & 5.7 & 11.2 & 5.1 & 0.86 \\
\hline $852-1-84-003$ & $10 / 23 / 84$ & 3.0 & 5.3 & 10.8 & 4.9 & 0.83 \\
\hline $852-1-84-005$ & $10 / 23 / 84$ & 3.0 & 4.4 & $10^{7}$ & 4.1 & 0.70 \\
\hline $852-1-85-001$ & $05 / 09 / 85$ & 3.4 & 5.6 & 10.3 & 5.4 & 0.91 \\
\hline $852-1-85-002$ & $05 / 09 / 85$ & 3.4 & 5.4 & 10.4 & 5.2 & 0.88 \\
\hline $852-1-85-003$ & $05 / 14 / 85$ & 3.5 & 5.5 & 9.5 & 5.7 & 0.96 \\
\hline $852-1-85-004$ & $05 / 14 / 75$ & 3.5 & 5.7 & 9.8 & 5.8 & 0.99 \\
\hline $852-1-85-005$ & $06 / 18 / 85$ & 4.8 & 4.8 & 8.5 & 5.6 & 0.95 \\
\hline
\end{tabular}

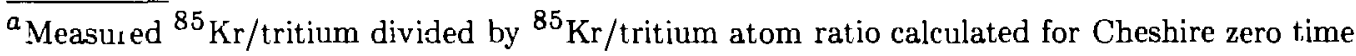
$\left(5.90 \times 10^{-4}\right)$.

surprising result. Our data set for nuclides other than tritium is rather limited, but it is interesting to see how their concentrations vary as a function of volume pumped. Several such plots are included in Fig. 6. Antimony-125 and ${ }^{35} \mathrm{Kr}$ show the same behavior as tritium, but ${ }^{137} \mathrm{Ce}$ and ${ }^{90} \mathrm{Sr}$ in water pumped through the new perforations show a marked decrease in concentration. Most of the other radionuclides listed in Table VIII (many of which are at barely detectable concentrations) show relatively small concentration changes when the new perforations were put into use. The graph in Fig. 5 indicates another peculiar aspect of our data. There appears to be an approximate decrease of $40 \%$ of the initial tritium concentration during removal of $8 \times 10^{6}$ gals. of water, implying a total reservoir volume of about $20 \times 10^{7}$ gals. However, calculations based on the yield of the test device indicate a cavity nearly five times larger than this. We will discuss possible reasons for the apparently anomalous data from Cheshire in Sec. III.C. 
TABLE VIII

RADIONUCLIDES IN WATER AT CHESHIRE ${ }^{a}$

\begin{tabular}{|c|c|c|c|c|c|}
\hline Date Collected & $09 / 08 / 83$ & $08 / 01 / 84$ & $10 / 23 / 84$ & $06 / 18 / 85$ & $06 / 18 / 85$ \\
\hline Ident. No. 852-9 & $-83-006$ & $-84-001$ & $-84-003$ & $-85-003$ & $-85-004$ \\
\hline & \multicolumn{5}{|c|}{$\begin{array}{l}\text { Volume Pumped } \\
\qquad\left(10^{6} \text { gals. }\right) \\
\end{array}$} \\
\hline & 0.06 & 0.17 & 3.0 & 4.8 & 4.8 \\
\hline${ }^{3} \mathrm{H}$ & $\begin{array}{c}1.23 \times 10^{13} \\
\left(5.91 \times 10^{-1}\right)\end{array}$ & $\begin{array}{c}1.12 \times 10^{13} \\
\left(5.38 \times 10^{-1}\right)\end{array}$ & $\begin{array}{c}1.08 \times 10^{13} \\
\left(5.19 \times 10^{-1}\right)\end{array}$ & $\begin{array}{c}8.5 \times 10^{12} \\
\left(4.1 \times 10^{-1}\right)\end{array}$ & $\begin{array}{c}8.5 \times 10^{12} \\
\left(4.1 \times 10^{-1}\right)\end{array}$ \\
\hline${ }^{22} V_{i 1}$ & $\begin{array}{c}4 \times 10^{4} \\
\left(9 \times 10^{-9}\right)\end{array}$ & $\begin{array}{c}3 \times 10^{4} \\
\left(7 \times 10^{-9}\right)\end{array}$ & $\begin{array}{c}3 \times 10^{4} \\
\left(7 \times 10^{-9}\right)\end{array}$ & $\begin{array}{c}8 \times 10^{3} \\
\left(2 \times 10^{-9}\right)\end{array}$ & $\begin{array}{c}5 \times 10^{3} \\
\left(1 \times 10^{-9}\right)\end{array}$ \\
\hline${ }^{40} \mathrm{~K}$ & $\begin{array}{c}4.7 \times 10^{12} \\
\left(5.1 \times 10^{-9}\right)\end{array}$ & $\begin{array}{c}5.0 \times 10^{12} \\
\left(5.4 \times 10^{-9}\right)\end{array}$ & $\begin{array}{c}4.4 \times 10^{12} \\
\left(4.7 \times 10^{-9}\right)\end{array}$ & $\begin{array}{c}1.2 \times 10^{13} \\
\left(1.3 \times 10^{-8}\right)\end{array}$ & $\begin{array}{c}8.3 \times 10^{12} \\
\left(8.9 \times 10^{-9}\right)\end{array}$ \\
\hline $60(0$ & $\begin{array}{c}2.3 \times 10^{3} \\
\left(2.6 \times 10^{-10}\right)\end{array}$ & $\begin{array}{c}4.0 \times 10^{3} \\
\left(4.5 \times 10^{-10}\right)\end{array}$ & $\begin{array}{c}1.2 \times 10^{3} \\
\left(1.4 \times 10^{-10}\right)\end{array}$ & $\begin{array}{c}1.9 \times 10^{3} \\
\left(2.1 \times 10^{-10}\right)\end{array}$ & $\begin{array}{c}8.3 \times 10^{2} \\
\left(9.3 \times 10^{-11}\right)\end{array}$ \\
\hline${ }^{85} \mathrm{Kr}$ & $\begin{array}{c}5.7 \times 10^{9} \\
\left(3.2 \times 10^{-4}\right)\end{array}$ & $\begin{array}{c}5.7 \times 10^{9} \\
\left(3.2 \times 10^{-4}\right)\end{array}$ & $\begin{array}{c}4.9 \times 10^{9} \\
\left(2.7 \times 10^{-4}\right)\end{array}$ & $\begin{array}{c}4.8 \times 10^{9} \\
\left(2.6 \times 10^{-4}\right)\end{array}$ & $\begin{array}{c}4.8 \times 10^{9} \\
\left(2.6 \times 10^{-4}\right)\end{array}$ \\
\hline $90 \mathrm{sr}$ & $\begin{array}{c}7.0 \times 10^{6} \\
\left(1.5 \times 10^{-7}\right)\end{array}$ & $\begin{array}{c}5.6 \times 10^{6} \\
\left(1.2 \times 10^{-7}\right)\end{array}$ & $\begin{array}{c}5.3 \times 10^{6} \\
\left(1.1 \times 10^{-7}\right)\end{array}$ & $\begin{array}{c}2.5 \times 10^{5} \\
\left(5.2 \times 10^{-9}\right)\end{array}$ & \\
\hline${ }^{106} \mathrm{Pu}$ & $\begin{array}{c}2 \times 10^{6} \\
\left(1 \times 10^{-6}\right)\end{array}$ & $\begin{array}{c}4 \times 10^{\hat{0}} \\
\left(2 \times 10^{-6}\right)\end{array}$ & $\begin{array}{c}2 \times 10^{6} \\
\left(1 \times 10^{-6}\right)\end{array}$ & $\begin{array}{c}6 \times 10^{6} \\
\left(3 \times 10^{-6}\right)\end{array}$ & $\begin{array}{c}2 \times 10^{6} \\
\left(1 \times 10^{-6}\right)\end{array}$ \\
\hline $125 \mathrm{sb}$ & $\begin{array}{c}1.5 \times 10^{7} \\
\left(3.2 \times 10^{-6}\right)\end{array}$ & $\begin{array}{c}1.6 \times 10^{7} \\
\left(3.4 \times 10^{-6}\right)\end{array}$ & $\begin{array}{c}1.3 \times 10^{7} \\
\left(2.8 \times 10^{-r,}\right)\end{array}$ & $\begin{array}{c}1.4 \times 10^{7} \\
\left(3.0 \times 10^{-6}\right)\end{array}$ & $\begin{array}{c}1.5 \times 10^{7} \\
\left(3.2 \times 10^{-6}\right)\end{array}$ \\
\hline${ }^{134} \mathrm{Cs}$ & $\begin{array}{c}3 \times 10^{4} \\
\left(1 \times 10^{-8}\right)\end{array}$ & $\begin{array}{c}4 \times 10^{4} \\
\left(1 \times 10^{-8}\right)\end{array}$ & $\begin{array}{c}4 \times 10^{4} \\
\left(1 \times 10^{-8}\right)\end{array}$ & $\begin{array}{c}3 \times 10^{3} \\
\left(1 \times 10^{-9}\right)\end{array}$ & Not detected \\
\hline $\begin{array}{l}{ }^{137} \mathrm{Cs} \\
\text { radiochem. }\end{array}$ & $\begin{array}{c}7.3 \times 10^{7} \\
\left(1.4 \times 10^{-6}\right)\end{array}$ & $\begin{array}{c}1.2 \times 10^{8} \\
\left(2.4 \times 10^{-6}\right)\end{array}$ & $\begin{array}{c}1.4 \times 10^{8} \\
\left(2.8 \times 10^{-6}\right)\end{array}$ & $\begin{array}{c}3.6 \times 10^{7} \\
\left(7.1 \times 10^{-7}\right)\end{array}$ & \\
\hline $\begin{array}{l}{ }^{137} \mathrm{Cs} \\
\text { gamma spec. }\end{array}$ & $\begin{array}{c}5.5 \times 10^{7} \\
\left(1.1 \times 10^{-6}\right)\end{array}$ & $\begin{array}{c}6.3 \times 10^{7} \\
\left(1.2 \times 10^{-6}\right)\end{array}$ & $\begin{array}{c}7.5 \times 10^{7} \\
\left(1.5 \times 10^{-6}\right)\end{array}$ & $\begin{array}{c}3.1 \times 10^{7} \\
\left(6.1 \times 10^{-7}\right)\end{array}$ & $\begin{array}{c}2.3 \times 10^{7} \\
\left(4.5 \times 10^{-7}\right)\end{array}$ \\
\hline
\end{tabular}


TABLE VIII (cont)

RADIONUCLIDES IN WATFR AT CHESHIRE ${ }^{a}$

\begin{tabular}{|c|c|c|c|c|c|}
\hline Date Collected & $09 / 08 / 83$ & $08 / 01 / 84$ & $10 / 23 / 84$ & $06 / 18 / 85$ & $06 / 18 / 85$ \\
\hline Ident. No. $852-9$ & $-83-006$ & $-84-001$ & $-84-003$ & $-85-003$ & $-85-004$ \\
\hline & \multicolumn{5}{|c|}{$\begin{array}{l}\text { Volume Pumped } \\
\left(10^{6} \text { gals. }\right)\end{array}$} \\
\hline & 0.06 & 0.17 & 3.0 & 4.8 & 4.8 \\
\hline${ }^{152} \mathrm{Eu}$ & $\begin{array}{c}10^{4} \\
\left(10^{-10}\right)\end{array}$ & $\begin{array}{c}10^{4} \\
\left(10^{-10}\right)\end{array}$ & $\begin{array}{c}10^{4} \\
\left(10^{-10}\right)\end{array}$ & $\begin{array}{c}x 10^{4} \\
\left(10^{-10}\right)\end{array}$ & $\begin{array}{c}10^{3} \\
\left(10^{-10}\right)\end{array}$ \\
\hline${ }^{154} \mathrm{Eu}$ & $\begin{array}{c}1 \times 10^{4} \\
\left(7 \times 10^{-10}\right)\end{array}$ & $\begin{array}{c}2 \times 10^{4} \\
\left(1 \times 10^{-9}\right)\end{array}$ & $\begin{array}{c}8 \times 10^{3} \\
\left(5 \times 10^{-10}\right)\end{array}$ & $\begin{array}{c}6 \times 10^{3} \\
\left(4 \times 10^{-10}\right)\end{array}$ & $\begin{array}{c}7 \times 10^{3} \\
\left(5 \times 10^{-10}\right)\end{array}$ \\
\hline${ }^{155} \mathrm{Eu}$ & $\begin{array}{c}10^{5} \\
\left(10^{-8}\right)\end{array}$ & $\begin{array}{c}10^{4} \\
\left(10^{-9}\right)\end{array}$ & $\begin{array}{c}10^{4} \\
\left(10^{-9}\right)\end{array}$ & $\begin{array}{c}10^{5} \\
\left(10^{-8}\right)\end{array}$ & $\begin{array}{c}10^{4} \\
\left(10^{-9}\right)\end{array}$ \\
\hline${ }^{239} \mathrm{Pu}$ & $\begin{array}{c}1 \times 10^{7} \\
\left(2 \times 10^{-10}\right)\end{array}$ & $\begin{array}{c}4 \times 10^{6} \\
\left(1 \times 10^{-10}\right)\end{array}$ & $\begin{array}{c}1 \times 10^{7} \\
\left(2 \times 10^{-10}\right)\end{array}$ & $\begin{array}{c}4 \times 10^{6} \\
\left(1 \times 10^{-10}\right)\end{array}$ & \\
\hline
\end{tabular}

${ }^{a}$ Units are atoms $/ \mathrm{m} \ell$ and $(\mu \mathrm{Ci} / \mathrm{m} \ell)$, both corrected to $t_{0}=02 / 14 / 76$.

\section{B. Comparison with Cambric}

In previous reports dealing with the Cambric site (for example, Ref. 3), we calculated "retention factors," which are a measure of the extent to which radionuclides produced by the nuclear explosion are retained in the soil in either a fused or sorbed state. In our annual report for FY 1985 (Ref. 8), we noted that the rhyolite of Pahute Mesa seemed to have retention factors similar to those of the alluvium at Cambric. The radionuclide concentrations measured in Cheshire samples during this past year confirm these earlier observations, and it does appear that despite differences in both the geologic media and the strength of the nuclear explosions at the two sites, the retention of product radionuclides by the solid material is similar at Cheshire and at Cambric. These measurements are of some importance, because most of the nuclear testing now done at the NTS is in rhyolite or alluvium. 


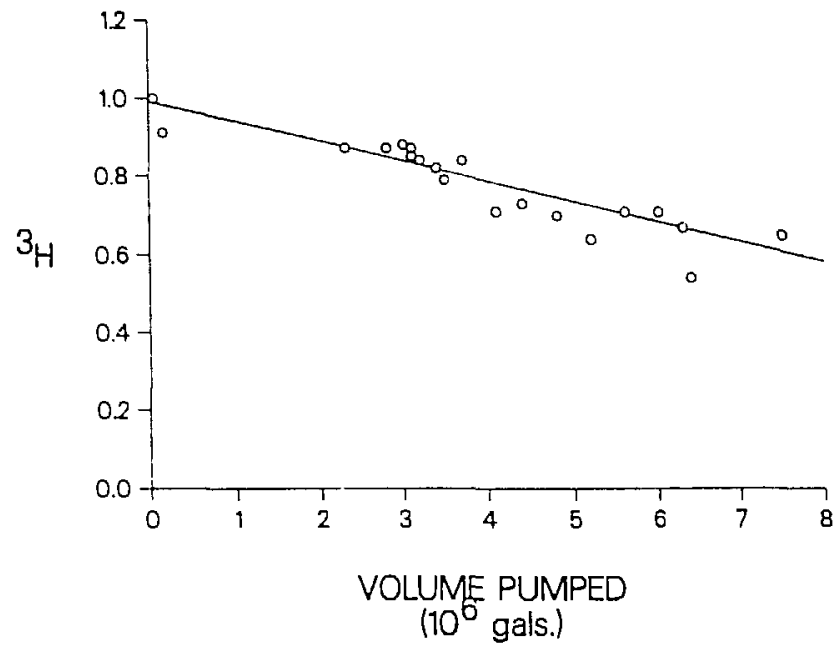

Fig. 5. Relative tritium concentration in water from Cheshire as a function of volume pumped. Values are corrected to Cheshire zero time.
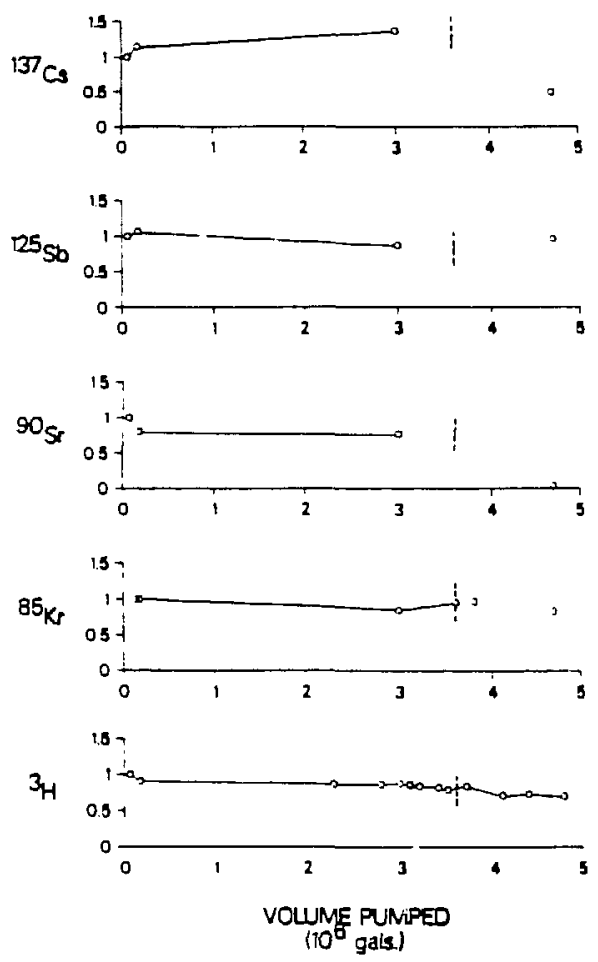

Fig. 6. Relative radionuclide concentration in water from Cheshire as a function of volume pumped. Values are corrected to Cheshire zero time. 


\section{Data Interpretation}

As indicated, there are still some uncertainties about the Cheshire study. In particular, we do not know the source of water that we arampling. Four points must be considered. (1) The concentrations of nonsorbing radionuclides like tritium and ${ }^{85} \mathrm{Kr}$ appear to be the same at wide? parated depths. (2) Fission products are present at both denths-even hiris ; sorbing elements like strontium and cesium, which normally are not expected to move very far through geologic media. (3) The rate at which tritium diminishes with pumping implies a containment reservoir with a volume much smaller than the volume calculated for the cavity. (4) None of the concentrations of tritium sampled from Cheshire have approached the calculated source-term values ${ }^{8}$ for this radionuclide.

It may be possible that the water nominally drawn into the hole casing at the two different depths is in fact entering at only one point. Pressure tests of the hole indicated that it was tight before the second set of perforations were made, but after that test the casing may have cracked or the bridge plug may have begun to leak. The lack of great differences in the radionuclide content of the water before and after the second perforations were made argues that the waters come from the same or very similar sources. The presence of fission products suggests that the water has not traveled great distances from the cavity/chimney region. It may be possible that some fission products were instantaneously injected along a fracture at the time of the explosion and thus are located much further away from the cavity than is normally expected. If an appreciable fraction of the product radionuclides and tritium were contained in a fracture or offshoot of the main cavity in the vicinity of the re-entry hole, this might result in an apparently excessive rate of tritium removal when the hole is pumped. In any event, it is not clear what the spatial relationship is between the two perforations, our sampling point(s), and the cavity. We have two more large-volume samples to analyze, one taken just before the second perforations were made, and one taken in November 1985. It may be that the additional data provided by these samples will help resolve some of the uncertainties discussed above. 
IV. STIDIES AT OTHER NTS SITES (J. L. Thompson, S. Maestas, and F. O. Lawrence)

() (casionally we have the opportunity to analyze water samples from sites that are not inchuded in the regular RNM surveillance. Although such samples (for example, from emplacenent holes) are usually available on a one-time-only basis, they can provide some information about the general status of radionuclide contcit in groundwater at the NTS. This past year wo sampled water from two sites where emplacement holes had filled with format ion water.

() April 4. 1985. wo obtained thee pressurized water samples from Hole U3kz. Our allalyses indicated a 1 ritium activity of $54 \times 10^{-2} \mu \mathrm{Ci} / \mathrm{m} \ell$ and a ${ }^{85} \mathrm{Kr}$ activity of $5.7 \times$ $10^{-5}{ }^{-5}\left(^{\prime} \mathrm{i} / \mathrm{m} f\right.$ in this water. These activity levels are only a factor of 2 less than comparable value's from ('heshime. so the water may have been drawn from the cavity region of a nearby earlier test. We hope to be able to obtain a large-volume sample from Hole U3kz to determine whether fission products are also present in the water.

In rontrast with those from Hole U3kz. samples of water obtained from Hole U4t contrined about $2.7 \times 10^{-7} \mu \mathrm{Ci} / \mathrm{m} \ell$ of tritium, which is essentially a background level. The Hole I' it sample was obtained September 11, 1985; we have no plans to analyze other simples from this hole.

V. LABORATORY AND (OMPITATIONAL WORK (B P. Bayhurst, M. R. Cisneros, L. S. Herman. D. E. Hobart. S. D. Knight, F. O. Lawrence. A. J. Mitchell, T. W. Newton, A. E. Ogard. M. A. Ott. P. D. Palmer, R. S. Rundberg, K. W. Thomas, J. L. Thompson, and B. J. Travis)

At this laboratory there is a long-term, extensive program pertaining to radionuclide interactions with the geologic media at the NTS. Initial research was conducted as part of the RNM projert: ${ }^{1}$ lat (or. studies were supported jointly by the RNM and NNWSI projects. ${ }^{9}$ For the latter project. we are evaluating the potential of Yucca Mountain (on the western edge of the NTS) as a repository fer nuclear wastes. A good deal of the NNWSI research is directly applicable to our RNM studies. For example, most of our understanding of sorption reactions of fission products on tuff has been raired through studies supported by 
both projeits. ${ }^{10}$ In this section we will review briefly some the NNWSI work accomplished during FY 1985 that is particularly relevant to the RNM project.

The effect of grouridwater composition on radionuclide sorption has been a subject of study at Los Alamos for some time. ${ }^{10}$ We recently reported ${ }^{11}$ that elements such as barium, cesium, and strontium, which sorb by an ion exchange merhanism, have appreciably lower sorption coefficients in a "high-salt" water such as that from Hole UE25p\#1 than in a low-salt water such as that from Well J-13. Other elements, such as uranium and selenium, showed little variation in sorption coefficient between these two waters, presumably because they do not sorb by ion exchange. Water with relatively high $\mathrm{pH}$ and low Eh generally increased the tendency of dissolved radioactive species to sorb on tuff. Long-term studies indicate that technetium and neptunium form stable species in groundwaters, and their sorption behavior does not change over a 15-month period. This last information is particularly relevant for the RNM project because we anticipate measuring the technetium content of archival samples from RNM-2S.

The behavior of plutonium in a groundwater environment is not well understood. and several studies bearing on this subject are under way. We are attempting to measure saturation concentrations and equilibrium constants for the system $\mathrm{Pu}(\mathrm{VI})-\mathrm{Pu}(\mathrm{V})-\mathrm{Pu}(\mathrm{IV})-$ $\mathrm{Pu}$ (colloid), as well as the effect of radiolysis on these parameters. ${ }^{12}$ Sorption or uptake of plutonium by microorganisms present in grrundwaters is being evaluated $;^{11}$ this appears to significantly affect the amount of dissolved plutonium in the groundwater/tuff system. We reported recently ${ }^{12}$ that plutonium tends to pass through short columns of crushed tuff at rates many times greater than would be predicted on the basis of sorption data. This behavior appears to be related to the oxidation state of the plutoninm; $\mathrm{Pu}(\mathrm{VI})$ and $\mathrm{Pu}(\mathrm{V})$ are relatively mobile. Also, we see evidence that plutonium polymer and americium colloidal particulates pass through these columns. ${ }^{11}$

The possibility of radionuclide transport in the form of colloids is receiving attention through a number of studies at the Laboratory. The concentration level of natural colloids present in water pumped from $\mathrm{Well} \mathrm{J}-13$ has recently been measured. ${ }^{11,12}$ We conclude that this water contains too little material to contribute appreciably to radionuclide transport of species that might sorb on the natural colloids. Sur autocorrelation photon spectroscopy 
system has been used to measure the size distribution of reference polystyrene beads in the range of 5 nm to $1 \mu m$ and to measure the size distribution of plutonium polymers. ${ }^{11}$ We have added population balance equations to the code TRACR3D so that we can simulate migration oi colloids through geologic media. ${ }^{10}$ These studies of colloid transport will be of great value to the RNM program if we undertake a field study of colloid migration at the R.N.M-1 sitc.

\section{ACKNOWLEDGMENTS}

We greatly appreciate the efforts of ('. E. Callegos. L. M. Mitcheil, J. Howard, and K. C'oen in typing this report and the editorial assistance of J. H. Heiken. We also thank P. A. Elder. M. E. Lark, and S. Lormuseanx for their assistance in gamma counting and spectral analysis.

\section{REFERENCES}

1. D. C. Hoffman, R. Stone, and W. W. Dudley, Jr., "Radioactivity in the Underground Environment of the Cambric Nuclear Explosion at the Nevada Test Site," Los Alamos Scientific Laboratory report LA-6877-MS (July 1977).

2. D. ('. Hoffman. "A Field Study in Radionuclide Migration," in Radioactive Waste in Cifologic Storage. S. Fried, Ed., ACS Symposium Series 100 (American Chemical Society. Washington, 2C, 1979), p. 149.

3. D. C. Hoffman, W. R. Daniels, K. Wolfsberg, J. L. Thompson, R. S. Rundberg, S. L. Fraser, and K. S. Daniels, "A Review of a Field Study of Radionuclide Migration from an Underground Nuclear Explosion," International Atomic Energy Agency report IAEA-CN-43/469 (1983).

4. W. R. Daniels, Ed., "Laboratory and Field Studies Related to the Radionuclide Migration Project, October 1, 1979 September 30, 1980," Los Alamos Nał onal Laboratory report LA-8670-PR (February 1981).

5. W. R. Daniels, Ed., "Laboratory and Field Studies Related to the Radionuclide Migration Project, October 1, 1980 - September 30, 1981," Los Alamos National Laboratory report LA-9192-PR (February 1982).

6. W. R. Daniels, Ed., "Laboratory and Field Studies Related to the Radionuclide Migration Project, October 1, 1981-September 30, 1982," Los Alamos National Laboratory report LA-9691-PR (May 1983). 
7. W. R. Daniels and J. L. Thompson, Comps. and Eds., "Laboratory and Field Studies Related to the Radionuclide Migration Project, October 1, 1982--September 30, 1983," Los Alamos National Laboratory report LA-10121-PR (April 1984).

8. J. L. Thompson, Comp. and Ed., "Laburatory and Field Studies Related to the Radionuclide Migration Project, October 1, 1983-September 30, 1984," Los Alamos National Laboratory report LA-10372-PR (February 1985).

9. K. Wolfsberg, B. P. Bayhurst, B. M. Crowe, W. R. Daniels, B. R. Erdal, F. O. Lawrence, A. E. Norris, and J. R. Smyth, "Sorption-Desorption Studies on Tuff. I. Initial Studies with Samples from the J-13 Drill Site, Jackass Flats, Nevada," Los Alamos Scientific Laboratory report LA-7480-MS (April 1979).

10. W. R. Daniels, K. Wolfsberg, R. S. Rundberg, A. E. Ogard, J. F. Kerrisk, C. J. Duffy, et al., "Summary Repurt on the Geochemistry of Yucca Mountain and Environs," Los Alamos National Laboratory report LA-9328-MS (December 1982).

11. K. W. Thomas, Comp., "Research and Development Related to the Nevada Nuclear Waste Storage Investigations, October 10--December 31, .984," Los Alamos National Laboratory report (in press).

12. C. J. Duffy, Comp., "Research and Development Related to the Nevada Nuclear Waste Storage Investigations, January 1-March 31, 1985," Los Alamos ational Laboratory report (in press). 